\title{
Substituent Effects on Regioselectivity of the Diels-Alder Reactions: Reactions of 10-Allyl-1,8-dichloroanthracene with 2-Chloroacrylonitrile, 1-Cyanovinyl Acetate and Phenyl Vinyl Sulfone
}

\author{
Mujeeb A. Sultan and Usama Karama \\ Chemistry Department, College of Science, King Saud University, P.O. Box 2455, Riyadh 11451, Saudi Arabia \\ Correspondence should be addressed to Mujeeb A. Sultan; maasultan@ksu.edu.sa
}

Received 16 March 2016; Accepted 4 July 2016

Academic Editor: Hakan Arslan

Copyright (C) 2016 M. A. Sultan and U. Karama. This is an open access article distributed under the Creative Commons Attribution License, which permits unrestricted use, distribution, and reproduction in any medium, provided the original work is properly cited.

Diels-Alder reaction of 10-allyl-1,8-dichloroanthracene (3) with 2-chloroacrylonitrile (4) and 1-cyanovinyl acetate (5) gives exclusively the ortho isomer while its reaction with phenyl vinyl sulfone (10) yields a mixture of two isomeric adducts with priority to ortho isomer. The reactions proceeded under microwave condition in xylene. Configurations of these isomers have been assigned with the help of NMR spectra. The results indicated that the steric effect is dominating toward the isomer regioselectivity in the Diels-Alder reaction of the present compounds.

\section{Introduction}

The Diels-Alder reaction is considered one of the most useful synthetic reactions and it is among the most atom economical and reliable carbon-carbon bond forming methods known in organic chemistry [1]. In this reaction, a conjugated diene the $4 \pi$ component (diene) reacts with an alkene, the $2 \pi$ component (dienophile) to build up six-member system. The importance of the Diels-Alder reaction arises from its reliability, versatility, and remarkable regio-stereoselectivity. Among all the dienes, anthracene derivatives have attracted considerable interest as one of the powerful dienes and their ability to react with various dienophiles through Diels-Alder reactions has been extensively investigated [2-11].

The Diels-Alder addition ethylene or ethylene equivalent to 9-substituted anthracene precursor was the key steps for the synthesis of some antidepressant and anxiety drugs such as benzoctamine, maprotiline, and homologues of these compounds [12-19].

The substituted anthracenes could be interesting targets for the study of regioselectivity and stereoselectivity in the Diels-Alder reactions. The investigation of the substituents effect on the Diels-Alder reaction of 10-allyl-1,8-dichloroanthracenes with dienophiles has not been reported yet. In this work, the regioselectivity of the Diels-Alder reaction of 10allyl-1,8-dichloroanthracenes (3) with 2-chloroacrylonitrile (4), 1-Cyanovinyl acetate (5), and Phenyl vinyl sulfone (10) has been studied. The structural elucidation of the cycloadducts has been made based on the NMR spectroscopic data.

\section{Results and Discussion}

The reduction of the starting material 1,8-dichloroanthraquinone (1) to afford 4,5-dichloroanthrone (2) was the first step toward the forward synthesis of the targets substituted10-allyl-1,8-dichloro-9,10-dihydro-9,10-ethanoanthracene (6, $7,11,12$ ). The intermediate 10 -allyl-1,8-dichloroanthracene (3) was prepared as described in the literature [20], since allylmagnesium bromide reacted with 4,5-dichloroanthrone (2) which was prepared based on the procedure reported by Goichi et al. [21] (Scheme 1). 
<smiles>C=CCCc1c2cccc(Cl)c2cc2c(Cl)c(C(N)(Br)Br)ccc12</smiles>

(1)

(2)

(3)

SCHEME 1: Preparation of the intermediate 10-allyl-1,8-dichloroanthracene (3).<smiles>C=CCc1c2cccc(Cl)c2cc2c(Cl)cccc12</smiles>

(3)

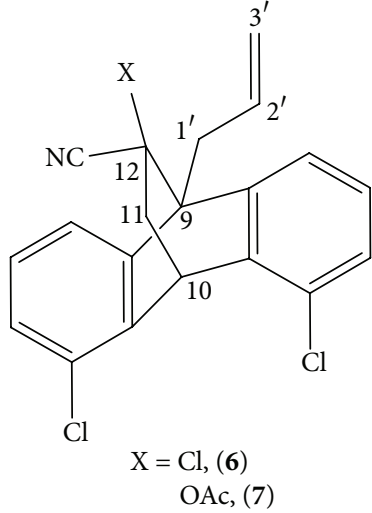$$
\mathrm{Cl},(4)
$$

OAc, (5)

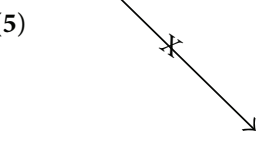

$\mathrm{X}=\mathrm{Cl},(\mathbf{8})$

OAc, (9)

Scheme 2: The Plausible Diels-Alder reaction of the ethylene equivalents (4) and (5) with 10-allyl-1,8-dichloroanthracene (3).

In continuation to our interest in anthracene derivatives $[19,22]$. Herein, we want to report our studies on the DielsAlder reaction of 10-allyl-1,8-dichloroanthracene (3) with 2-chloroacrylonitrile (4), 1-cyanovinyl acetate (5), and phenyl vinyl sulfone (10). The Diels-Alder reaction between 10-allyl1,8-dichloroanthracene (3) and ketene equivalent 2-chloroacrylonitrile (4) proceeded smoothly under microwave condition to give only one isomer (6) in 95\% yield, and the reaction of 10-allyl-1,8-dichloroanthracene (3) with 1-cyanovinyl acetate (5) under the same conditions afforded $85 \%$ of the isomer (7) (Scheme 2). Despite the nature difference between chlorine as an electron withdrawing atom and acetate as an electron donating group, their effect as substituents beside the nitrile group on the dienophile is in the same direction and apparently favored toward the formation of the one isomer. It is clear that chlorine and acetate substituents on the dienophile exhibited no steric effect, subsequently the formation of the other putative isomers (8) and (9) is not favored.

The nature of the diene and dienophile substituent has been successfully exploited in assigning the configuration and regioselectivity of various Diels-Alder adducts [23, 24], and when employed to our adducts this effect discloses considerable information. The ${ }^{1} \mathrm{H}-\mathrm{NMR}$ of the isomer (6) exhibited a downfield triplet signal, as result of chlorine effect, at $\delta 5.49$ ppm with coupling constant $J 2.9 \mathrm{~Hz}$; this signal integrated for the bridge-head proton $\mathrm{H}-10$. Due to the bending of the isomer as demonstrated by the crystal structure, the two protons assigned for $\mathrm{C} 11$ were nonequivalent and displayed two double doublet signals regions at $\delta 2.38$ and $2.85 \mathrm{ppm}$. 


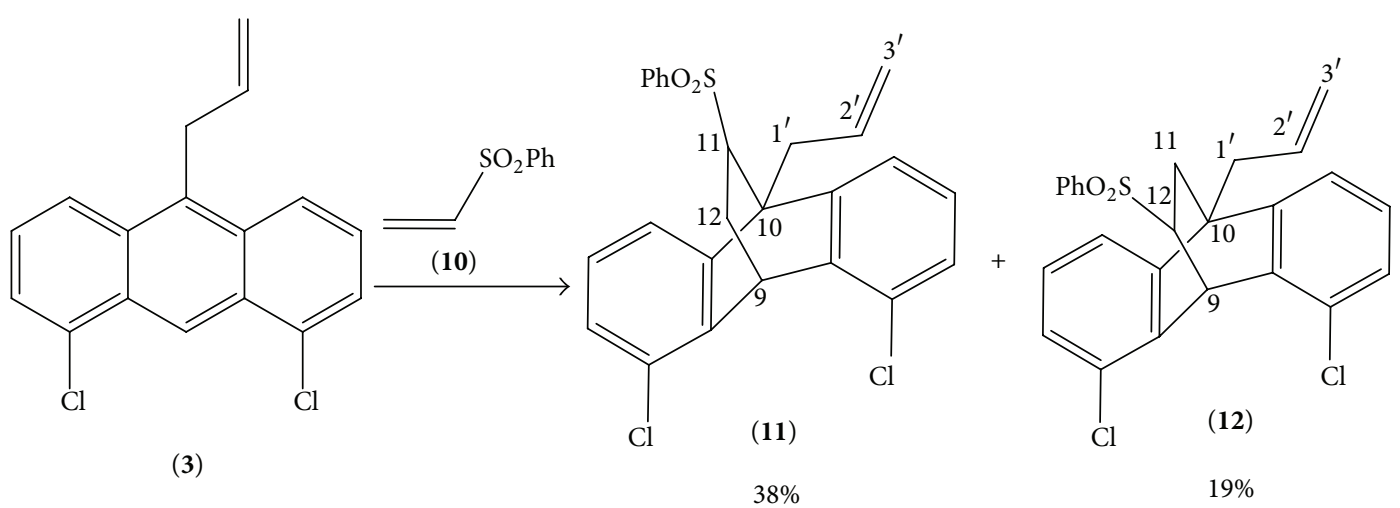

Scheme 3: The Diels-Alder cycloaddition of phenyl vinyl sulfone (10) with 10-allyl-1,8-dichloroanthracene (3).

The structural elucidation of the isomer (7) by ${ }^{1} \mathrm{H}-\mathrm{NMR}$ and ${ }^{13} \mathrm{C}-\mathrm{NMR}$ is similar, with small variation in chemical shifts, to the isomer (6).

The Diels-Alder reaction, where the formation of more than one isomer is possible, has been studied. The DielsAlder reaction between 10-allyl-1,8-dichloroanthracene (3) and phenyl vinyl sulfone (10) led to isomers (11) and (12) as regioisomers in 57\% yield under microwave conditions in xylene. The isomers were easily separated by silica gel column chromatography with the eluent system ethyl acetate:petroleum ether $(1: 5)$. The reaction favours the formation of the ortho isomer (11), the ratio of the isomers (ortho: meta) was $2: 1$. This isomers ratio indicated that the transition state containing the phenyl sulfone functionality above the chlorine atom is less stable than the other possibility (Scheme 3).

The obtained isomers are due to the fact that both the 10-allyl-1,8-dichloroanthracene (3) (diene) and phenyl vinyl sulfone (10) (dienophile) are unsymmetrical. It is noteworthy to mention the big size of the phenyl group on the dienophile (10), so its steric effect enforces the formation of the meta isomer (12) in contrast to dienophiles (4) and (5), where the substituents effect led to no formation of the putative isomer isomers (8) and (9).

The assignment of the ortho isomer (11) and the meta isomer (12) by ${ }^{1} \mathrm{H}-\mathrm{NMR}$ analysis was not troublesome. The ${ }^{1} \mathrm{H}-\mathrm{NMR}$ results could unambiguously distinguish between the regioisomers; the bridge-head proton $\mathrm{H}-9$ of the ortho isomer (11) has triplet signal appearing at $\delta 5.4 \mathrm{ppm}$ with coupling constants $J=2.9 \mathrm{~Hz}$ whereas the bridge-head proton $\mathrm{H}-9$ of meta isomer (12) has doublet signal at $5.57 \mathrm{ppm}$ with coupling constants $J=1.4 \mathrm{~Hz}$ integrated, respectively. The downfield shifting of the H-9 in the meta isomer (12) is a result of deshielding effect of the phenyl sulfone group, since this group is more closer to $\mathrm{H}-9$ in case of meta isomer (12).

\section{Experimental}

3.1. Synthesis of 4,5-Dichloroanthracene-9-one (2). To a stirred suspension of the 1,8-dichloroanthraquinone (1) $(10 \mathrm{~g}$, $36.10 \mathrm{mmol})$ in methanol $(720 \mathrm{~mL}), \mathrm{NaBH}_{4}(6.8 \mathrm{~g}, 180 \mathrm{mmol})$ was added slowly in small portions over $5 \mathrm{~h}$ and the solution was further stirred for $1 \mathrm{~h}$ at room temperature. $90 \mathrm{~mL}$ of the conc. $\mathrm{HCl}$ was added and the reaction mixture was refluxed for $1 \mathrm{~h}$ and then cooled to room temperature. The formed solid was filtered through suction funnel, washed with $\mathrm{H}_{2} \mathrm{O}$, and air-dried. This crude product was purified via flash column chromatography on silica gel using $\mathrm{CH}_{2} \mathrm{Cl}_{2} /$ hexane $(1: 10$ and then $1: 1)$ to afford (2).

Yield 89\%; yellow powder; m.p. $192^{\circ} \mathrm{C}$. IR $(\mathrm{KBr}): v=$ 3433, 3078, 2925, 1659, 1584, 1446, 1391, 1312, 1130, 961, 871, $741,660 \mathrm{~cm}^{-1}$. ${ }^{1} \mathrm{HNMR}\left(\mathrm{CDCl}_{3}, 400 \mathrm{MHz}\right): \delta=4.15(\mathrm{~s} ;$ $2 \mathrm{H}, H-10), 7.41(\mathrm{t} ; J=8.0,2 \mathrm{H}, \operatorname{Ar} H), 7.64-7.66(\mathrm{~m}, 2 \mathrm{H}$, $\operatorname{Ar} H), 8.24$ (dd; $J=1.4,1.4 \mathrm{~Hz}, 2 \mathrm{H}, \operatorname{Ar} H)$ ppm. ${ }^{13} \mathrm{C}$ NMR $\left(\mathrm{CDCl}_{3}, 100 \mathrm{MHz}\right): \delta=29.3,126.2,128,132.7,133.6,134,137.2$, $182.5 \mathrm{ppm}$. MS (EI): $m / z(\%)=262(35)\left[\mathrm{M}^{+}\right], 229(27), 227$ (100), 199 (27), 163 (48). HRMS (EI): Calcd. For $\mathrm{C}_{14} \mathrm{H}_{8} \mathrm{OCl}_{2}$ $\left[\mathrm{M}^{+}\right]$261.9952, Found 261.9954 .

3.2. Synthesis of 10-Allyl-1,8-dichloroanthracene (3). A twoneck round-bottom flask containing 4,5-dichloroanthrone (2) $(5 \mathrm{~g}, 19 \mathrm{mmol})$ was equipped with a magnetic stirrer, a rubber septum-sealed funnel connected with side joint and the other joint was connected to a balloon of nitrogen. The flask was evacuated and flushed with nitrogen two times; then $80 \mathrm{~mL}$ of dry THF was injected into the flask. The solution was cooled to $0^{\circ} \mathrm{C}$ and allylmagnesium bromide $\left(1.0 \mathrm{M}\right.$ in $\left.\mathrm{Et}_{2} \mathrm{O}, 25 \mathrm{~mL}, 25 \mathrm{mmol}\right)$ was added dropwise. The solution was then stirred at room temperature for $1 \mathrm{~h}$ and quenched with $1 \mathrm{M} \mathrm{HCl}(120 \mathrm{~mL})$. The organic layer was separated and the aqueous layer was extracted with $\mathrm{Et}_{2} \mathrm{O}$ $(2 \times 100 \mathrm{~mL})$, and the combined organic solution was dried over $\mathrm{Na}_{2} \mathrm{SO}_{4}$ and then evaporated the solvent. The residue was redissolved in $80 \mathrm{~mL}$ of toluene and $10 \mathrm{~g}$ of $\mathrm{P}_{2} \mathrm{O}_{5}$ was added. The mixture was stirred for $1.5 \mathrm{~h}$. Then, it was poured slowly over $160 \mathrm{~mL}$ of $\mathrm{NaHCO}_{3}$, extracted with $\mathrm{Et}_{2} \mathrm{O}(2 \times$ $100 \mathrm{~mL}$ ), washed with $200 \mathrm{~mL}$ of water, dried over $\mathrm{Na}_{2} \mathrm{SO}_{4}$, and evaporated. The residue obtained was purified via flash column chromatography on silica gel using hexane and then hexane/ $\mathrm{CH}_{2} \mathrm{Cl}_{2} 90: 10$ to afford (3).

Yield 55\%; yellow powder; m.p. $105^{\circ} \mathrm{C}$. IR $(\mathrm{KBr}): v=$ 3074, 2980,1751, 1619,1433, 1335, 1219, 1065, 914, 873, 791, $728 \mathrm{~cm}^{-1} .{ }^{1} \mathrm{HNMR}\left(\mathrm{CDCl}_{3}, 400 \mathrm{MHz}\right): \delta=4.21(\mathrm{~d} ; J=$ $\left.5.1 \mathrm{~Hz}, 2 \mathrm{H}, H-1^{\prime}\right), 4.75\left(\mathrm{dd} ; J=1.4,16.8 \mathrm{~Hz}, 1 \mathrm{H}, H-3^{\prime}\right)$, 
$4.97\left(\mathrm{dd} ; J=1.4,10.2 \mathrm{~Hz}, 1 \mathrm{H}, H-3^{\prime}\right), 6.0-6.10\left(\mathrm{~m} ; 1 \mathrm{H}, H-2^{\prime}\right)$, $7.31(\mathrm{t} ; J=8.0 \mathrm{~Hz}, 2 \mathrm{H}, \operatorname{ArH}), 7.51(\mathrm{~d} ; J=7.3 \mathrm{~Hz}, 2 \mathrm{H}, \mathrm{ArH}), 8.01$ (d; $J=8.8 \mathrm{~Hz}, 2 \mathrm{H}, \operatorname{Ar} H$ ), $9.16(\mathrm{~s}, 1 \mathrm{H}, H-9)$ ppm. ${ }^{13} \mathrm{C} \mathrm{NMR}$ $\left(\mathrm{CDCl}_{3}, 100 \mathrm{MHz}\right): \delta=32.4,116.4,120.3,123.6,125.5,125.6$, $129.1,130.9,133.0,133.1,135.7 \mathrm{ppm}$. MS (EI): $m / z(\%)=286(9)$ $\left[\mathrm{M}^{+}\right], 263$ (7), 219 (60), 131 (39), 100 (4), 69 (100). HRMS (EI): Calcd. For $\mathrm{C}_{17} \mathrm{H}_{12} \mathrm{Cl}_{2}\left[\mathrm{M}^{+}\right]$286.0317, Found 286.0316.

3.3. General Synthesis of Substituted-10-Allyl-1,8-dichloro-9,10dihydro-9,10-ethanoanthracene. An oven-dried $10 \mathrm{~mL}$ microwave reaction vessel containing a stir bar was charged with a solution of 10-allyl-1,8-dichloroanthracene (3) $(6 \mathrm{mmol})$ in $(3.5 \mathrm{~mL})$ xylene and dienophile reagent $(7.2 \mathrm{mmol})$. The vessel was sealed with a plastic microwave septum. The vessel was placed into the Microwave CEM Discover SP system under the following conditions: stirring was set high. Power max was kept on. Maximum power and maximum pressure were set $250 \mathrm{~W}$ and $250 \mathrm{psi}$, respectively, with a set temperature of $150^{\circ} \mathrm{C}$ for $40 \mathrm{~h}$. After microwave irradiation was complete, the mixture was cooled to room temperature and the solvent removed in vacuo. The residue was purified via column chromatography on silica gel using ethyl acetate/petroleum ether $(1: 5)$ to afford the corresponding cycloadduct.

3.3.1. 9-Allyl-4,5,12-trichloro-9,10-dihydro-9,10-ethanoanthracene-12-carbonitrile (6). Yield 79\%; pale yellow powder; m.p. $180^{\circ} \mathrm{C}$. IR (KBr): $v=3073,2925,2856,2235,1731,1579,1446$, $1236,1093,979,923,790 \mathrm{~cm}^{-1} .1 \mathrm{HNMR}\left(\mathrm{CDCl}_{3}, 400 \mathrm{MHz}\right): \delta$ $=2.38(\mathrm{dd}, J=2.9,13.9 \mathrm{~Hz}, 1 \mathrm{H}, H-11), 2.85(\mathrm{dd}, J=2.9,14.6 \mathrm{~Hz}$, $1 \mathrm{H}, H-11), 3.55-3.61\left(\mathrm{~m}, 1 \mathrm{H}, H-1^{\prime}\right), 3.73-3.80\left(\mathrm{~m}, 1 \mathrm{H}, H-1^{\prime}\right)$, $5.47\left(\mathrm{dd} ; J=1.4,17.6 \mathrm{~Hz}, 1 \mathrm{H}, H-3^{\prime}\right), 5.34(\mathrm{dd}, J=1.4,10.2 \mathrm{~Hz}$, $\left.1 \mathrm{H}, H-3^{\prime}\right), 5.49(\mathrm{t} ; J=2.9 \mathrm{~Hz}, 1 \mathrm{H}, H-10), 5.92-6.01(\mathrm{~m} ; 1 \mathrm{H}, \mathrm{H}-$ $2^{\prime}$ ), 7.17-7.22 (m; 2H, ArH), 7.31-7.34 (m; 2H, ArH), 7.41 (d; J $=7.3 \mathrm{~Hz}, 1 \mathrm{H}, \mathrm{ArH}), 7.48(\mathrm{~d} ; J=7.3,1 \mathrm{H}, \mathrm{ArH}) \mathrm{ppm} .{ }^{13} \mathrm{C} \mathrm{NMR}$ $\left(\mathrm{CDCl}_{3}, 100 \mathrm{MHz}\right): \delta=31.0,35.7,35.9,47.5,54.6,60.7,118.3$, $129.7,129.8,133.5,138.4,138.6,139.1,139.7 \mathrm{ppm}$. MS (EI): $\mathrm{m} / z$ $(\%)=373\left(\left[\mathrm{M}^{+}\right]\right.$, not recorded $), 339(22), 337(27), 326(43)$, 304 (52), 286 (100), 251 (58), 216 (44), 215 (49), 89 (41), 87 (88).

3.3.2. 9-Allyl-4,5-dichloro-12-cyano-9,10-dihydro-9,10-ethanoanthracen-12-yl acetate (7). Yield 84.3\%; white powder; m.p. $202^{\circ} \mathrm{C}$. IR (KBr): $v=3079,2983,2853,1751,1639,1445,1371$, 1227, 1014, 920, $781 \mathrm{~cm}^{-1}$. ${ }^{1} \mathrm{HNMR}\left(\mathrm{CDCl}_{3}, 400 \mathrm{MHz}\right): \delta=$ $1.94\left(\mathrm{~s}, 3 \mathrm{H}, \mathrm{CO}_{2} \mathrm{CH}_{3}\right), 1.98$ (d; $\left.J=2.9 \mathrm{~Hz}, 1 \mathrm{H}, H-11\right), 2.8$ (dd, $J$ $=2.9,2.9 \mathrm{~Hz}, 1 \mathrm{H}, H-11), 3.59-3.62\left(\mathrm{~m}, 2 \mathrm{H}, H-1^{\prime}\right), 5.31(\mathrm{dd} ; J=$ $\left.1.4,10.2 \mathrm{~Hz}, 1 \mathrm{H}, H-3^{\prime}\right), 5.43-5.49$ (m; $\left.2 \mathrm{H}, H-10, H-3^{\prime}\right)$, 5.976.07 (m; 1H, H-2' $), 7.14-7.20(\mathrm{~m} ; 2 \mathrm{H}, \mathrm{ArH}), 7.25-7.31(\mathrm{~m} ; 2 \mathrm{H}$, $\operatorname{ArH}), 7.42$ (d; $J=7.3 \mathrm{~Hz}, 1 \mathrm{H}, \operatorname{Ar} H), 7.49$ (d; $J=8.0 \mathrm{~Hz}, 1 \mathrm{H}$, ArH) ppm. ${ }^{13} \mathrm{C} \mathrm{NMR}\left(\mathrm{CDCl}_{3}, 100 \mathrm{MHz}\right): \delta=20.6,30.3,35.7$, 43.5, 53.3, 76.0, 117.1, 118.4, 124.7, 124.9, 127.1, 127.6, 127.7, 128.2, $129.5,129.8,133.9,139.0,139.1,139.7,139.8,168.6$ ppm. MS (EI): $m / z(\%)=397\left(\left[\mathrm{M}^{+}\right]\right.$, not recorded $), 337(12), 288(49), 286$ (100), 251 (99), 216 (92), 215 (82), 189 (13).

3.3.3. 10-Allyl-1,8-dichloro-11-(phenylsulfonyl)-9,10-dihydro-9, 10-ethanoanthracene (11). Yield 38\%; white powder; m.p. $86^{\circ} \mathrm{C} . \mathrm{IR}(\mathrm{KBr}): v=3071,2935,2252,1730,1635,1580,1441$, 992, 913, 775, 731, 680, $577 \mathrm{~cm}^{-1} \cdot{ }^{1} \mathrm{HNMR}\left(\mathrm{CDCl}_{3}, 400 \mathrm{MHz}\right)$ : $\delta=0.86-0.95(\mathrm{~m} ; 2 \mathrm{H}, H-12), 1.14-1.28\left(\mathrm{~m} ; 2 \mathrm{H}, H-1^{\prime}\right), 1.82$ $(\mathrm{t} ; J=11 \mathrm{~Hz}, 1 \mathrm{H}, H-11), 5.36\left(\mathrm{~d} ; J=9.5 \mathrm{~Hz}, 1 \mathrm{H}, H-3^{\prime}\right), 5.4(\mathrm{t}$; $J=2.9 \mathrm{~Hz}, 1 \mathrm{H}, H-9), 5.54\left(\mathrm{~d} ; J=16.8 \mathrm{~Hz}, 1 \mathrm{H}, H-3^{\prime}\right), 6.05-$ $6.3\left(\mathrm{~m} ; 1 \mathrm{H}, H-2^{\prime}\right), 7.05-7.08(\mathrm{~m} ; 1 \mathrm{H}, \operatorname{ArH}), 7.13-7.17(\mathrm{~m} ; 2 \mathrm{H}$, ArH), 7.24-7.26 (m; 1H, ArH), 7.39-7.47 (m; 4H, ArH), 7.52$7.56(\mathrm{~m} ; 1 \mathrm{H}, \mathrm{ArH}), 7.66-7.68(\mathrm{~m} ; 2 \mathrm{H}, \mathrm{ArH}) \mathrm{ppm} .{ }^{13} \mathrm{C} \mathrm{NMR}$ (DMSO, $100 \mathrm{MHz}): \delta=31.1,33.0,35.3,48.0,54.9,117.8,123.2$, $126.4,126.6,127.2,127.4,127.8,127.9,128.3,129.2,133.6,135.2$, 139.5, 139.7 ppm. MS (EI): $m / z(\%)=454(8)\left[\mathrm{M}^{+}\right], 313(18)$, 288 (47), 286 (100), 251 (16), 67 (13). HRMS (EI): Calcd. For $\mathrm{C}_{25} \mathrm{H}_{20} \mathrm{O}_{2} \mathrm{SCl}_{2}\left[\mathrm{M}^{+}\right]$454.0561, Found 454.0543.

3.3.4. 10-Allyl-1,8-dichloro-12-(phenylsulfonyl)-9,10-dihydro-9, 10-ethanoanthracene (12). Yield 19\%; white powder; m.p. $91^{\circ} \mathrm{C} . \mathrm{IR}(\mathrm{KBr}): \nu=3071,2969,2928,2853,1634,1582,1451$, 1312, 1148, 995, 921, $778 \mathrm{~cm}^{-1}$. ${ }^{1} \mathrm{HNMR}\left(\mathrm{CDCl}_{3}, 400 \mathrm{MHz}\right)$ : $\delta=1.90-1.97(\mathrm{~m} ; 1 \mathrm{H}, H-11), 2.01-2.06(\mathrm{~m} ; 1 \mathrm{H}, H-11), 3.15-$ $3.23\left(\mathrm{~m} ; 2 \mathrm{H}, H-1^{\prime}\right), 3.37-3.42(\mathrm{~m} ; 1 \mathrm{H}, H-12), 5.21(\mathrm{dd} ; J=1.4$, $\left.10.2 \mathrm{~Hz}, 1 \mathrm{H}, H-3^{\prime}\right), 5.31\left(\mathrm{dd}, J=1.4,16.8 \mathrm{~Hz}, 1 \mathrm{H}, H-3^{\prime}\right), 5.57$ (d; $J=1.4 \mathrm{~Hz}, 1 \mathrm{H}, \mathrm{H}-9), 6.05-6.12\left(\mathrm{~m} ; 1 \mathrm{H}, \mathrm{H}-2^{\prime}\right), 6.96-7.05$ (m; $3 \mathrm{H}, \mathrm{ArH}), 7.13-7.18(\mathrm{~m} ; 3 \mathrm{H}, \mathrm{ArH}) .7 .46-7.50(\mathrm{~m} ; 2 \mathrm{H}, \mathrm{ArH})$, 7.56-7.60 (m; 1H, ArH). 7.89-7.91 (m; 2H, ArH) ppm. ${ }^{13} \mathrm{C}$ $\operatorname{NMR}\left(\mathrm{CDCl}_{3}, 100 \mathrm{MHz}\right): \delta=32.4,35.5,37.1,45.5,62.9,119.2$, $119.9,121.1,126.6,126.8,127.3,127.4,127.9,128.7,129.1,129.3$, $129.5,131.8,133.4,133.7,136.1,138.3,138.4,139.4,146.7$ ppm. MS (EI): $m / z(\%)=454(8)\left[\mathrm{M}^{+}\right], 313(18), 288(47), 286(100)$, 251 (16), 67 (13). HRMS (EI): Calcd. For $\mathrm{C}_{25} \mathrm{H}_{20} \mathrm{O}_{2} \mathrm{SCl}_{2}\left[\mathrm{M}^{+}\right]$ 454.0561, Found 454.0543.

\section{Conclusion}

In conclusion, this is the first study reporting the regioselectivity of the Diels-Alder reaction of 10-allyl-1,8-dichloroanthracene with three different-substituted dienophiles. The reactions successfully proceeded under microwave conditions in xylene. The dienophiles, 2-chloroacrylonitrile, and 1cyanoacetate gave exclusively the ortho isomer, while phenyl vinyl sulfone led to the formation of the ortho and meta isomers with priority to ortho isomer. The results indicate that steric effect is dominating in deciding the isomer regioselectivity in the Diels-Alder reaction of the present compounds.

\section{Competing Interests}

The authors declare no conflict of interests.

\section{Acknowledgments}

The authors extend their appreciation to the Deanship of Scientific Research at King Saud University, for funding the work through the research group Project No. RGP-128.

\section{References}

[1] T. J. Brocksom, J. Nakamura, M. L. Ferreira, and U. Brocksom, "The diels-alder reaction: an update," Journal of the Brazilian Chemical Society, vol. 12, no. 5, pp. 597-622, 2001. 
[2] K. Müller and H. Prinz, "Antipsoriatic anthrones with modulated redox properties. 4. Synthesis and biological activity of novel 9,10-dihydro-1,8-dihydroxy-9-oxo-2- anthracenecarboxylic and -hydroxamic acids," Journal of Medicinal Chemistry, vol. 40, no. 17, pp. 2780-2787, 1997.

[3] H. Prinz, Y. Ishii, T. Hirano et al., "Novel benzylidene$9(10 \mathrm{H})$-anthracenones as highly active antimicrotubule agents. Synthesis, antiproliferative activity, and inhibition of tubulin polymerization," Journal of Medicinal Chemistry, vol. 46, no. 15, pp. 3382-3394, 2003.

[4] J.-H. Lin, A. Elangovan, and T.-I. Ho, "Structure-property relationships in conjugated donor-acceptor molecules based on cyanoanthracene: computational and experimental studies," The Journal of Organic Chemistry, vol. 70, no. 18, pp. 7397-7407, 2005.

[5] Y.-H. Liao, H. Zhang, Z.-J. Wu, L.-F. Cun, X.-M. Zhang, and W.-C. Yuan, "Enantioselective Michael addition of anthrone to nitroalkenes catalyzed by bifunctional thiourea-tertiary amines," Tetrahedron: Asymmetry, vol. 20, no. 20, pp. 23972402, 2009.

[6] S. A. Hasbullah and S. Jones, "Evaluating the use of chiral anthracene templates to access pyroglutamic acids," Tetrahedron: Asymmetry, vol. 21, no. 21-22, pp. 2719-2725, 2010.

[7] Y. W. Goh and J. M. White, "Structure correlation study of some DielsAlder cycloadducts of anthracene," Australian Journal of Chemistry, vol. 62, no. 5, pp. 419-424, 2009.

[8] P. Camps, T. Gómez, and A. Otermin, "Improved synthesis of a functionalized 2,8-ethanonoradamantane derivative," Tetrahedron, vol. 70, no. 34, pp. 5190-5196, 2014.

[9] R. Khan, T. P. Singh, and M. D. Singh, "Highly regioselective Diels-Alder reaction of 9-substituted anthracenes with citraconic anhydride," Synlett, vol. 25, no. 5, pp. 696-700, 2014.

[10] J. C. C. Atherton and S. Jones, "Diels-Alder reactions of anthracene, 9-substituted anthracenes and 9,10-disubstituted anthracenes," Tetrahedron, vol. 59, no. 46, pp. 9039-9057, 2003.

[11] K. Nikitin, H. Müller-Bunz, and M. J. McGlinchey, "Dielsalder reactions of 9-ferrocenyl- and 9,10-diferrocenylanthracene: steric control of 9,10- versus 1,4-cycloaddition," Organometallics, vol. 32, no. 20, pp. 6118-6129, 2013.

[12] M. Wilhelm and P. Schmidt, "Synthese und Eigenschaften von 1-Aminoalkyl-dibenzo[b, e] bicyclo[2.2.2] octadienen," Helvetica Chimica Acta, vol. 52, no. 6, pp. 1385-1395, 1969.

[13] U. Karama, A. Al-Saidey, Z. Al-Othman, and A. R. Almansour, "Synthesis of 2-(9,10-dihydro-9,10-propanoanthracen-9-yl)-Nmethylethanamine via a [4+2] cycloaddition," Molecules, vol. 15, no. 6, pp. 4201-4206, 2010.

[14] U. Karama, A. Al-Saidey, and A. R. Almansour, "Synthesis of bishomobenzoctamine 2-(9,10-dihydro-9,10-propanoanthracen-9-yl)-N-methylethanamine," Journal of Chemical Research, vol. 34, no. 5, pp. 241-242, 2010.

[15] S. Alibert, C. Santelli-Rouvier, B. Pradines et al., "Synthesis and effects on chloroquine susceptibility in Plasmodium falciparum of a series of new dihydroanthracene derivatives," Journal of Medicinal Chemistry, vol. 45, no. 15, pp. 3195-3209, 2002.

[16] J. R. Shah, P. D. Mosier, S. Peddi, B. L. Roth, and R. B. Westkaemper, "9-Aminomethyl-9,10-dihydroanthracene (AMDA) analogs as structural probes for steric tolerance in 5-HT2A and $\mathrm{H} 1$ receptor binding sites," Bioorganic \& Medicinal Chemistry Letters, vol. 20, no. 3, pp. 935-938, 2010.

[17] Y. M. McNamara, S. A. Bright, A. J. Byrne et al., "Synthesis and antiproliferative action of a novel series of maprotiline analogues," European Journal of Medicinal Chemistry, vol. 71, pp. 333-353, 2014.

[18] E. I. Snyder and R. A. Clement, "Some syntheses and structures in the 9,10-dihydro-9,10-ethanoanthracene series. Ia ", Journal of the American Chemical Society, vol. 82, no. 6, pp. 1424-1427, 1960.

[19] U. Karama, M. A. Sultan, A. I. Almansour, and K. E. El-Taher, "Synthesis of chlorinated tetracyclic compounds and testing for their potential antidepressant effect in mice," Molecules, vol. 21, no. 1, article 61, 2016.

[20] C. Rodríguez-Escrich, R. L. Davis, H. Jiang, J. Stiller, T. K. Johansen, and K. A. Jørgensen, "Breaking symmetry with symmetry: bifacial selectivity in the asymmetric cycloaddition of anthracene derivatives," Chemistry - A European Journal, vol. 19, no. 9, pp. 2932-2936, 2013.

[21] M. Goichi, K. Segawa, S. Suzuki, and S. Toyota, "Improved synthesis of 1,8-diiodoanthracene and its application to the synthesis of multiple phenylethynyl-substituted anthracenes," Synthesis, no. 13, pp. 2116-2118, 2005.

[22] U. KaramaI, M. A. SultanI, H. A. Ghabour II, H. K. Fun II, and I. K. Warad, "Crystal structure of 4, 5-dichloro-anthracen-9 $(10 \mathrm{H})$-one, $\mathrm{C}_{14} \mathrm{H}_{8} \mathrm{Cl}_{2} \mathrm{O}$," Zeitschrift für Kristallographie, vol. 228, no. 3, pp. 405-406, 1991.

[23] S. Verma and R. Singh, "Assignment of configurations to adducts of 2-substituted anthracene with maleic anhydride by N.M.R. spectroscopy," Australian Journal of Chemistry, vol. 29, no. 6, pp. 1215-1222, 1976.

[24] S. M. Verma and M. D. Singh, "Structural elucidation with nuclear magnetic resonance spectroscopy. Diels-Alder adducts of 1-aminoanthracene and maleic anhydride: restricted rotation about the aryl C(1)-N bond and intrinsic asymmetry about the imide (Nsp2-Csp3) system," The Journal of Organic Chemistry, vol. 42, no. 23, pp. 3736-3740, 1977. 

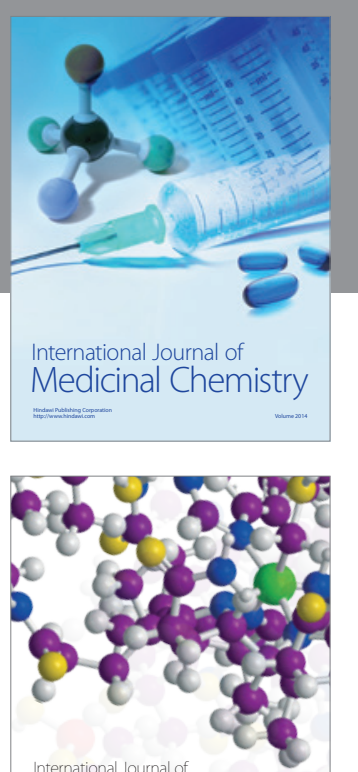

Carbohydrate Chemistry

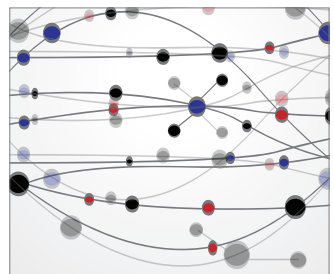

The Scientific World Journal
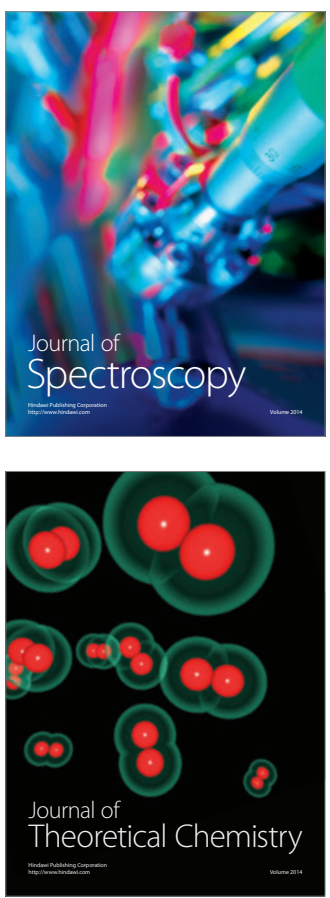
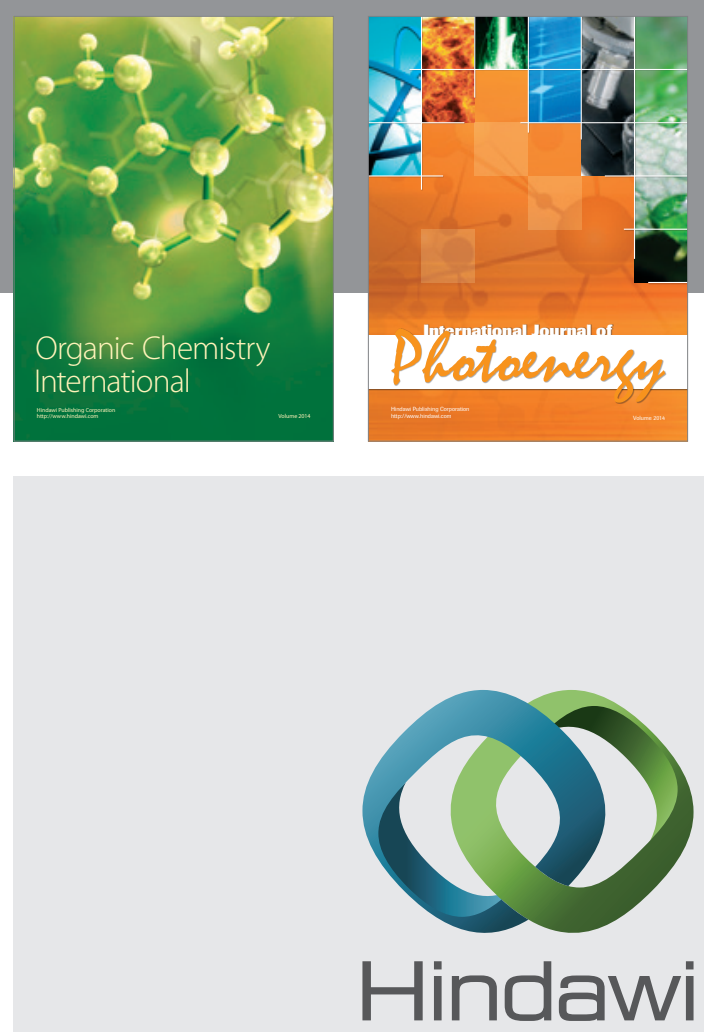

Submit your manuscripts at

http://www.hindawi.com

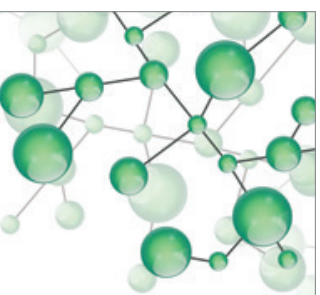

International Journal of

Inorganic Chemistry

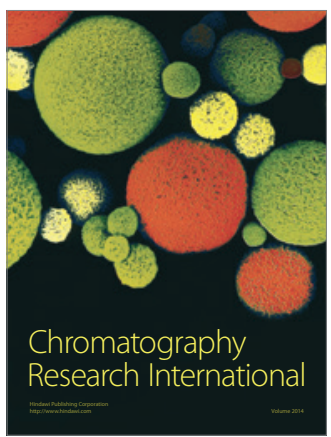

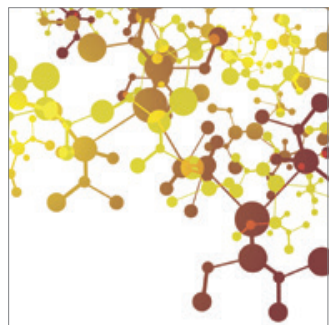

Applied Chemistry
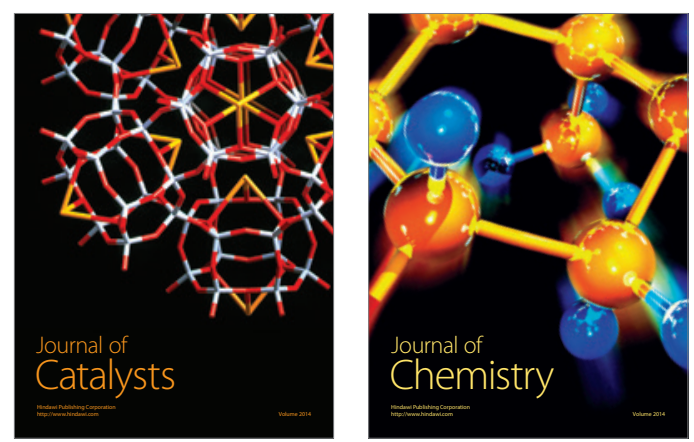
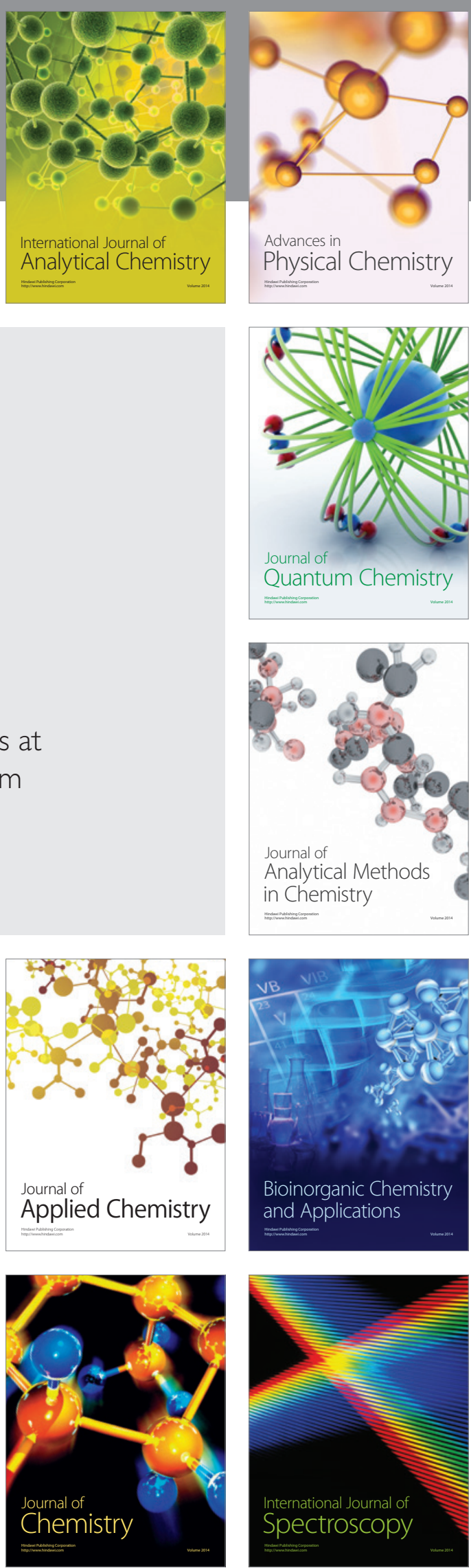